Owing to the Government's restrictions on the use of power in industry, including printing, we have been obliged to defer publication of some letters and print others in shortened form. We regret this inconvenience. Correspondents are asked to help by keeping their letters as short as possible.

\section{Guardians of Ethics}

K. McPherson, PH.D.............241

Screening for Phenylketonuria

M. d'A. Crawfurd, M.R.C.PATH.; T. M.

Andrews, PH.D., M.R.C.P., and R. $O$.

McKeran; Isabel Smith, M.B., and others;

S. F. Cahalane, F.R.C.PATH.........241

Pain after Birth

J. C. Moir, F.R.C.o.G.; W. I. C. Morris,

F.R.C.o.G. $\ldots \ldots \ldots \ldots \ldots \ldots \ldots \ldots \ldots \ldots 242$

Oncological Centres

H. Bush, M.R.C.P., and others.........243

Psychiatric Safeguards

J. C. Gunn, M.D., M.R.C.PSYCH.; H. Cairns,

M.R.C.G.P..................243

Cancer and the Patient

Mary A. J. T. Douglas, M.D., and others. . . 243

Glucagon Therapy in Acute Pancreatitis

R. B. Welbourn, F.R.C.S., and A. G. Cox,

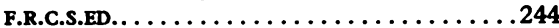

Amphotericin Pharmacophobia and Renal Toxicity

W. R. Forgan-Smith, M.B., and J. H.

Darrell, M.R.C.PATH. . .............244

Toxoplasmosis and Embryopathy

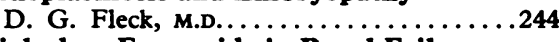

High-dose Frusemide in Renal Failure

D. Ganeval, M.D., and others. . . . . . . . 244

Correction of Serum Calcium Measure-

ments

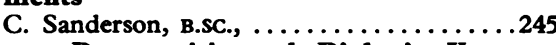

Acute Pancreatitis and Diabetic Keto-

acidosis in Hypothermia

R. E. G. Sloan, M.B... $\ldots \ldots \ldots \ldots \ldots 245$

Effect of Viruses on Lymphocyte Re-

activity

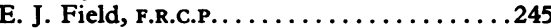

Incidence of Postpartum Deep Vein

Thrombosis in the Tropics

T. Chumnijarakij ...............245
Breast Milk Substitute

A. E. Ifekwunigwe, M.R.C.P., and D. B.

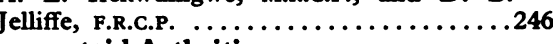

Rheumatoid Arthritis

G. P. Rodnan, M.D. . . . . . . . . . . . . 246

Possible Hazard of Methacrylate

Monomer

D. M. Gruebel Lee, F.R.C.s. . . . . . . . . 246

Preleukaemic Syndrome and Marrow Hypoplasia

N. K. Shinton, F.R.C.P., and D. G. Wells,

M.R.C.PATH. . . . . . . . . . . . . . . 246

Autoimmune Reactions in Chronic Liver

Disease

M. Torruella and others. . . . . . . . . . 247

B.M.A. and R.H.C.S.A.

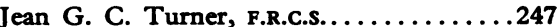

Transfer of Registrars

R. Maggs, F.R.C.PSYCH.; J. M. Potter,

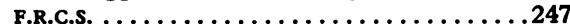

SIR,-I was interested to read your leading article (1 December, p. 502) on the existence and composition of ethical committees. Though I have not yet read the report of the committee of the Royal College of Physicians I have found a significant absence in most discussions of this subject. This is that the recognition of the need for expertise in experimental design is seldom acknowledged. In a very obvious way this requirement is fundamental to any discussion of ethics in medical experimentation. For while a proposed experiment might be judged ethical, it is usually so judged on the assumption that the experiment is capable of demonstrating what its planners would require it to demonstrate. That this might easily not be the case (but even if it is there might be more economical or sensible experimental designs to do the same or more) is seldom part of the discussion.
This is not merely an academic point for it has unfortunately been my experience that many proposed experiments will have little chance of demonstrating any treatment effect that is less than enormous with the number of patients envisaged. Its practical relevance now becomes more compelling as research workers are required to satisfy not only ethical committees but also funding organizations, and this leads to the temptation to try to research as many questions as possible with as little experimental effort as possible. Then the need for good experimental design becomes paramount if limited resources (and, of course, lives) are not to be wasted.-I am, etc.,

\section{K. MCPHERSON}

Department of Preventive Medicine,

Harvard University Medical School,
Boston, Massachusetts

\section{Screening for Phenylketonuria}

SIR,-Dr. B. Winokur and Dr. F. E. James's suggestion (5 January, p. 39) that pregnant women should be screened for hyperphenylalinaemia, rather than newborn infants for phenylketonuria, is at first sight attractive. However, they seem to assume that a Guthrie test on a single blood sample will suffice to detect heterozygotes for classical phenylketonuria as well as homozygotes for milder variants. Unfortunately, the detection of heterozygotes is not so simple.

Though the mean fasting level of phenylalanine is raised in heterogygotes as compared with controls, there is an overlap between the two groups of about $15 \%$. Even using a phenylalanine tolerance test, there is still appreciable overlap. ${ }^{2-4}$ Jervis $^{5}$ involves phenylalanine hydroxylase, the enzyme known to be defective in affected homozygotes, by showing that a large dose of phenylalanine produced a smaller rise in plasma tyrosine in heterozygotes than in controls. Rosenblatt and Scriver $^{6}$ exploited this observation to improve further the discrimination of heterozygotes by measuring both phenylalanine and tyrosine in a midday blood sample on an amino-acid analyser and then plotting the phenylalanine: tyrosine ratio against phenylalanine concentration. They confirmed the appreciable overlap in phenylalanine concentrations between heterozygotes and controls and found that the ratio plotted against concentration correctly dis- established that the defect in heterozygotes criminated 42 out of 43 subjects ( 25 controls and 18 known heterozygotes).

Such methods are of value in research and genetic counselling, but are too elaborate for use in screening. The ideal test for heterozygotes would be a direct assay of phenylalanine hydroxylase, but as the enzyme is not detectable in red or white blood cells by current methods this is not practicable. It is possible that a low-cost simplified modification of Rosenblatt and Scriver's procedure could be developed, using the Guthrie or a chromatographic method, with or without a previous phenylalanine load. If this were to be successfully achieved, then Drs. Winokur and James's suggestion should be seriously considered.-I am, etc.,

Department of Genetics,

M. D'A CRAWFURD University of Leeds

1 Knox, W. E., and Messinger, E., American Fournal of Human Genetics, 1958, 10, 53. Isia, D. Y.-Y., Driscoll, K., Troll, W., and Knox, W. E., Nature, 1956, 178, 1239.

Berry, H., Sutherland, B. S., and Guest, G. M. American foumal of Human Genetics, 1957, 9 , 310.

Perry, T. L., Tischler, B., Hansen, S., and MacDougall,' L., Clinica Chimica Acta,' 1967,

15, 47.
5 Jervis, G. A., Clinica Chimica Acta, 1960, 5, 471. Rosenblatt, D., and Scriver, C. R., Nature, 1968 , 218, 677.

SIR,-In their recent letter (5 January, p. 39), Drs. B. Winokur and F. E. James suggest that "consideration should be given to screening pregnant primiparous women with the Guthrie test rather than screening all infants for phenylketonuria" and later that "once a woman is found to be normal (as far as phenylalanine is concerned) there will be no need to test her again or to screen any of her subsequent offspring."

It is frequently impossible to confirm the 